\title{
Histological and Ultrasonographic Monitoring of Folliculogenesis in Puerperal Ewes after Spring Lambing
}

\author{
R. VLČKOVÁ ${ }^{1}$, I. VALOCKÝ ${ }^{2}$, G. LAZAR ${ }^{2}$, D. SOPKOVÁ ${ }^{1}$, I. MARAČEK ${ }^{1}$ \\ ${ }^{1}$ Department of Normal Anatomy, Histology and Physiology, Institute of Physiology \\ ${ }^{2}$ Clinic of Gynaecology and Obstetrics, University of Veterinary Medicine, Košice, Slovak Republic
}

Received July 6, 2007

Accepted November 15, 2007

\begin{abstract}
Vlčková R., I. Valocký, G. Lazar, D. Sopková, I. Maraček: Histological and Ultrasonographic Monitoring of Folliculogenesis in Puerperal Ewes after Spring Lambing. Acta Vet. Brno 2008, 77: 65-72.

The time of the first ovulation depends on the sheep breed, feeding conditions, year season, length of lamb nursing and following galactopoiesis. The objective of the present study was to analyse the follicle status after parturition in non-lactating Improved Valachian ewes. Laparotomy with following ovariectomy was performed after lamb weaning (spring) on days 17, 24 and 32 after parturition. The ovaries were USG analysed with $5.0 \mathrm{MHz}$ linear and 7.5 MHz convex transducer. Follicular data were analysed quantitatively and qualitatively. The ovaries were collected at the end of laparotomy and fixed in $10 \%$ formalin. The sections of the ovarian tissue were stained with haematoxylin and eosin and Azan staining. Ovarian slides were microscopically studied and analysed by LUCIA-G ver. 4.71. The differences in the ovary size were not significant. The number of follicles $<3 \mathrm{~mm}$ monitored by USG on day 32 was higher than that on day 17 after parturition. The image analysis of the ovary sections showed significantly higher numbers in the total follicles $(P<0.05)$ and the follicles $>3 \mathrm{~mm}(P<0.001)$. The rate of atresia was $82 \%$ and $89 \%$ on day 17 and on day 32 post partum, respectively. We observed single ovulation on day 17 and double ovulations on days 24 and 32 post partum. More than half of the total number of antral follicles visible on the ovary surface was prepared for recruitment and this number was higher on day 32 post partum. Follicle selection connected with a relatively low rate of atresia and responsible preovulatory follicle sizes opened the way for selecting more follicles for the dominance process and thus also for the occurrence of double ovulations.
\end{abstract}

Postpartum period, Improved Valachian sheep, follicle, atresia, ultrasonography, histology

At present and in the last years there has been no new information available on the follicle progress in the postpartum period of ewes. Folliculogenesis in the puerperium progresses in certain waves, similarly as in cows (Gong et al. 2002; Huszenicza et al. 1999; Hunter et al. 2004; Hernandez et al. 2005). The timing of the first ovulation is determined by the influence of the year season together with lamb suckling. In consequence of this longlasting period of lamb dependence on the ewe (or the seasonal character of sexual functions in spite of a relatively quick start of tertiary follicle growing waves), the first ovulation after parturition generally occurs at the beginning of the following oestrous mating season (the end of August and beginning of September). In dependence on the breed and feeding conditions in flocks, ewes may ovulate 60 - 70 days after parturition. Ultrasonic imaging is a highly accurate and rapid method for assessing ovarian structures (Griffin and Ginther 1992). Linear-array, real-time B-mode ultrasound scanners are best suited for veterinary applications involving dairy cattle (Fricke 2002) and sheep reproduction. An ultrasound scanner equipped with a $7.5 \mathrm{MHz}$ transducer is more useful for studying small ovarian structures such as developing follicles because of the greater image detail. In this study, we analysed the follicle status after parturition in unmilked ewes using the USG and his-

Address for correspondence:

MVDr. Radoslava Vlčková

Katedra anatómie, histológie a fyziológie, Ústav fyziológie

Univerzita veterinárskeho lekárstva

Komenského 73

04181 Košice, SR

Phone: +421903019545

Fax: + 421556334768

E-mail:radkavl@seznam.cz

http://www.vfu.cz/acta-vet/actavet.htm 
tological methods of image analysis (LUCIA-G ver. 4.71). We tried to compare these two methods and conclude the exactness of using the USG technique.

\section{Materials and Methods}

Experimental animals

Experiments were carried out on the agricultural cooperative farm of the Low Tatras region (altitude 600 $1000 \mathrm{~m})$ on twenty ewe ovaries in the spring puerperal period (April) - on day $17(\mathrm{n}=6), 24(\mathrm{n}=8)$ and 32 $(n=6)$. The ewes earmarked for the experiment were $4-10$ years old, of the Improved Vallachian breed, weighing $45-50 \mathrm{~kg}$, and were in middle body condition (BCS $2.5-3.5$ ). In winter the feeding ration consisted of grass silage, meadow hay, halite and mineral licks. Ewes were flushed with maize grit $750 \mathrm{~g}$ per head and day.

Laparotomic ultrasonography of ovaries

Laparotomy with following ovariectomy was carried out in field conditions on days 17, 24 and 32 after parturition. The animals were fasted for 12 - 18 hours before surgery. General anaesthesia was induced using sodium pentobarbital (Hall et al. 1993; Němeček 1996). The ewes were tied up on stretchers in the back position and placed on a sloping plane. The section place was cut, shaved off, degreased and disinfected. The abdominal cavity was sectioned in linea alba $5 \mathrm{~cm}$ cranially from the mammary gland. The ovaries were carefully pulled through the operation wound, ultrasonographically analysed using a real-time B-mode echo camera (Sono ACE - 600V; Medison Co., Korea) connected to a $5 \mathrm{MHz}$ linear transducer. The ovarian images were printed using the Video Graphic Printer (SONY UP - 880/890 CE/ 890 MD; Sony Co., Japan). Some ovarian images were recorded on diskettes using a real-time B-mode echo camera (ESAOTE Falco; ESAOTE S.p.A, Italy) connected to a 5.0/7.5 $\mathrm{MHz}$ convex transducer. The ovaries were examined directly on their surfaces. At the end of ultrasonography the ovaries were cut for histological processing.

Follicular data analysis of ultrasonography

Follicular data were analysed from ultrasonograms quantitatively and qualitatively according to the methods of Dickie et al. (1999) and Bartlewski et al. (2000). Both the number and diameter of antral follicles $<3 \mathrm{~mm}$ (small anechoic structures in the ovary), follicles $\geq 3 \mathrm{~mm}$, echoic and anechoic ovarian structures were studied (Grygar and Kudláč 1997; Battocchio et al. 1999).

Ovary sampling for histology processing

The ovaries were collected up at the end of laparotomy, cut to smaller sections and fixed in $10 \%$ formalin neutralized with powder $\mathrm{Ca}_{2} \mathrm{CO}_{3}$. Then they were washed in $1 \% \mathrm{KOH}$ solution dissolved in $80 \%$ ethanol for $5 \mathrm{~h}$, followed by water washing for $1 \mathrm{~h}$. Fixed and rinsed ovarian sections were drained in the increasing line of ethanol, supersaturated by methyl salicylate and benzene paraffin, embedded in paraffin and sectioned at $5-7 \mu$. The ovary tissue sections were stained with Mayer haematoxylin and eosin and we tried to stain some slides with Azan. The procedure of staining was performed according to Vacek (1990). The stained sections were fixed in Canadian balsam.

The prepared ovarian slides were studied using the PC System for Image Processing LUCIA-G version 4.71 connected to the PAL GKB CCD camera CC-8603 for light microscopy by ZEISS Axiolab (Carl Zeiss Co., Germany). The ovary sections were directly scanned using the Scanner hp scanjet 5550c method with technical improvement by the reduction (hp scanjet tma 5500c/5550c) for histological slides (Halagan and Maraček, unpublished data). Every $20^{\text {th }}$ section was evaluated. We studied the number and sizes of surface antral follicles $<3 \mathrm{~mm}$ and $\geq 3 \mathrm{~mm}$ and follicles were analysed as healthy or atretic according to Marion et al. (1968). We considered the follicles as atretic with the following changes: (1) loosening and sloughing of granulosa cells lining the antrum, (2) disappearance of membrana basalis and loss of orientation of the basal layer of the granulosum, (3) shortening and rounding of the theca interna cells, (4) reduced size of follicles and disorganized cell layers, (5) antrum filled with fibrous granulosa remnants, hyalinized theca layers, (6) oocyte and cumulus complex degeneration.

Statistical analysis

The values obtained from the ultrasonographic ovary and follicle measurements and ovarian slides were statistically assessed by the arithmetic mean and standard deviation (S.D.). Statistical differences were assessed by Student's $t$-test (Prism 3.0). Statistical significance was defined as $P<0.05$ and $P<0.001$.

\section{Results}

Characteristics of ovaries and follicle status after laparotomic ultrasonography The right ovaries were smallest on day 17 and largest on day 32 of the puerperal period. The mean size of the left ovaries was smaller on day 32 than that on day 24 and larger than that on day 17 (Fig. 1). The differences were not significant.

Using the laparotomic USG monitoring (Fig. 2) we observed a significantly higher number of follicles $<3 \mathrm{~mm}$ on day $32(P<0.05,61 \%$ follicles for recruitment $)$ compared 


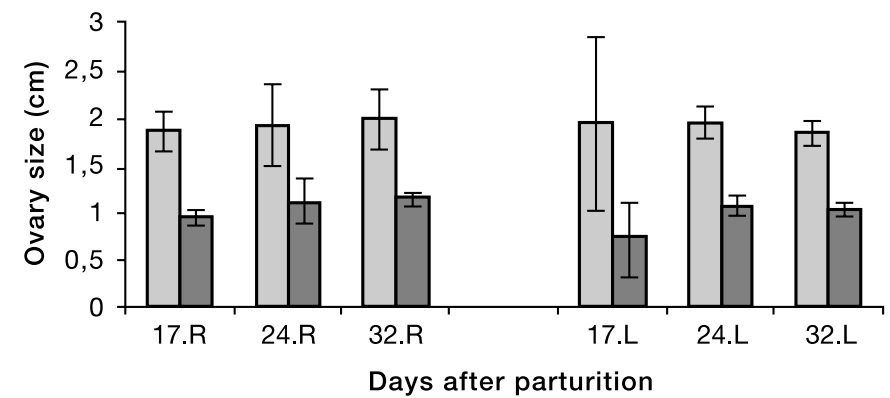

Fig. 1. Sizes of postpartum ewe ovary (mean $\pm \mathrm{SD} ; \mathrm{n}_{\mathrm{o17}}=6, \mathrm{n}_{024}=8, \mathrm{n}_{032}=6$ ); length (dark columns) and width (light columns); R - right ovary, L - left ovary.

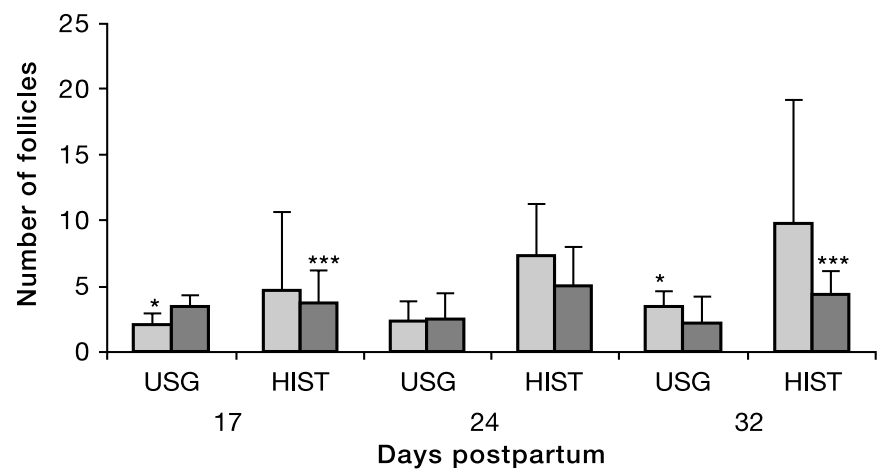

Fig. 3. Comparisons in number of follicles visible on the ovary surface (means $\pm \mathrm{SD} ; \mathrm{n}_{\mathrm{o17}}=6, \mathrm{n}_{\mathrm{o} 24}=8, \mathrm{n}_{\mathrm{032}}=$ 6) obtained by USG and histological image analysis (LUCIA-G v. 4.71); light columns - number of follicles $<3 \mathrm{~mm}$, dark columns - number of follicles $>3 \mathrm{~mm}$; USG - USG analysis, HIST - histological image analysis; * $(P<0.05),{ }^{* * *}(P<0.001)$.

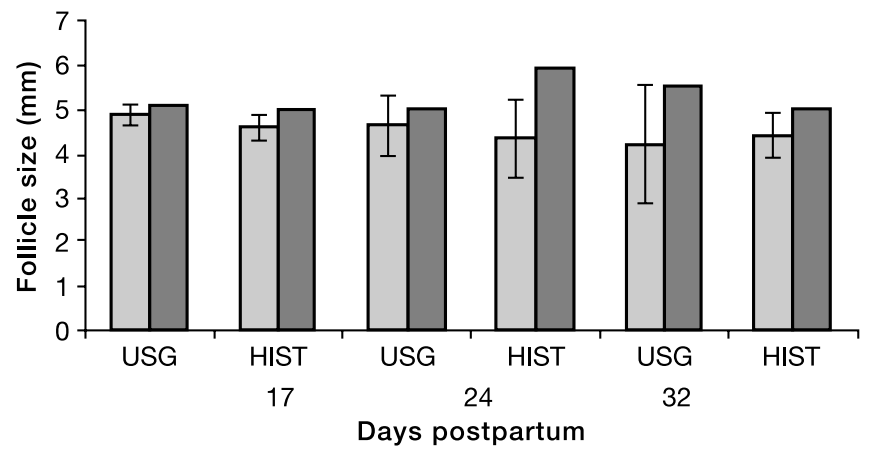

Fig. 4. Average size of the largest follicles and the size of the largest follicle visible on the ovary surface (mean $\pm \mathrm{SD} ; \mathrm{n}_{\mathrm{o} 17}=6, \mathrm{n}_{\mathrm{o} 24}=8, \mathrm{n}_{\mathrm{o} 22}=6$ ) obtained by USG and histological image analysis (LUCIA-G v. 4.71); light columns - average size of the largest follicles, dark columns - size of the largest follicle; USG - USG analysis, HIST - histological image analysis.

to day 17 (37\% follicles for recruitment) after parturition (Fig. 3). Other different numbers of follicles were not significant. Measurement of the diameter of follicles (Fig. 4) did not reveal any significant differences between the following days, but it was smaller on days 17 to 32 . We observed $67 \%$ run ovulations on day $17,75 \%$ on day 24 with $50 \%$ double 


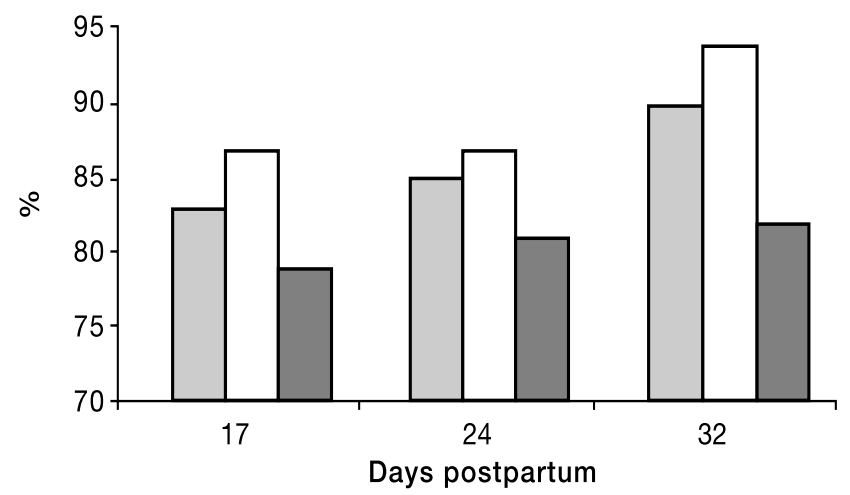

Fig. 5. Rate of atresia; white columns - follicles $<3 \mathrm{~mm}$, light columns - total follicle number, dark columns follicles $>3 \mathrm{~mm}$.

ovulations and $33 \%$ on day 32 post partum with half occurrence of double ovulation (Table 1).

Table 1. Occurrence of run double ovulation in postpartum ewes

\begin{tabular}{|l|c|c|c|}
\hline $\begin{array}{l}\text { Ovulation } \\
\text { occurrence }\end{array}$ & $\begin{array}{c}\text { Day 17 pp } \\
(\mathrm{n}=6)\end{array}$ & $\begin{array}{c}\text { Day 24 pp } \\
(\mathrm{n}=8)\end{array}$ & $\begin{array}{c}\text { Day 32 pp } \\
(\mathrm{n}=6)\end{array}$ \\
\hline Single & 2 & 2 & 0 \\
\hline Double & 0 & 2 & 1 \\
\hline
\end{tabular}

$\mathrm{pp}$ - postpartum, $\mathrm{n}$ - animal number

32 (31\% follicles for selection) compared to day 17 (44\% follicles for selection) (Fig. 3). The rate of atresia (total number of follicles) was $82 \%$ on day $17,89 \%$ on day 32 post partum and was related to the lower number of healthy follicles but not significantly (Fig. 5).

The number of small and large antral follicles undergone atresia (Fig. 5) was higher on day 32 post partum (small antral follicles: day $17-86 \%$, and $93 \%$ on day 32; large antral follicles: day $17-78 \%$, and $81 \%$ on day 32 ). The average diameter of the largest follicles was smaller on day $24(4.36 \pm 0.87)$ and larger on day 32 , but on that day the diameter of the largest follicle was larger than on the other following days (Fig. 4).

\section{Discussion}

Folliculogenesis in ewes in the postpartum period occurs in certain waves, similar to cows (Gong et al. 2002; Huszenicza et al. 1999; Hunter et al. 2004; Hernandez et al. 2005). The term of the first postpartum ovulation determines the influence of the year period and suckling of lambs. Breeding ewes with seasonal sexual activity, impregnated in the autumn oestrous mating season became pregnant and lambed at the end of winter or at the beginning of spring. Then the ewes nursed their lambs for approximately 3 months. In consequence of that or of sexual function seasonality, the first ovulation after parturition occurred generally only at the beginning of the following oestrous mating season at the end of August and at the beginning of September. However, in dependence on the breed and feeding conditions in flocks there may be a relatively high number of ewes with ovulation on days 60 - 70 after parturition. In the present study, we observed ovulations occurring earlier, on day 17 post partum in the spring lambing period with the highest number on day 24 post partum. The ovulation number and number of double ovulations were lower 
on day 32 post partum. These observations disagree with the findings of some authors (Bartlewski et al. 1999; Notter et al. 2003; Gábor et al. 2004; Lazar et al. 2004) who described the first ovulation/cyclic ovarian function of ewes lambed in the autumn season approximately 35 - 45 days after lambing. We observed the smallest ovaries on day 17 post partum. On day 24 the left ovary and on day 32 the right ovary dominated, which is in agreement with the observations of Dickie et al. (1999). The ovary size depends on the number and size of present follicles, on CL presence and congestion of these structures. It also depends on the ovarian and sexual cycle.

During laparotomy, we observed an increased number of large antral follicles and very low number of small antral follicles in the period studied. According to Hall et al. (1993), the number of small follicles ascertained during laparotomy is higher on day 20 post partum and numbers and sizes of follicles found on day 17 near to particulars found during laparotomy after progesterone implantation treatment in the anoestrous period.

By the ultrasonographic examination of ovaries using a $5.0 \mathrm{MHz}$ transducer we obtained better penetration through tissue and less detailed image. The opposite situation occurs after using a $7.5 \mathrm{MHz}$ transducer - poorer penetration through tissue and better image (Grygar and Kudláč 1997). The ultrasonographic scanner equipped with 5.0 MHz transducer is the best one used in practice for monitoring the bovine reproductive apparatus. Small ovarian structures (developing follicles) are best imaged by a 7.5 MHz transducer. The physiological status of follicles/CL cannot be determined during one-time USG examination as we did. Moreover, USG imaging helps to differentiate the anatomical structural characters on one hand, but on the other hand it is less informative about the physiological and endocrine status (Fricke 2002). USG examination of ovaries is faster and less stressful for animals than laparoscopy/laparotomy (Schrick et al. 1993).

More than half of the total number of follicles create small antral follicles and we observed them as lowest on day 17 and as highest on day 32. The numbers of large antral follicles were highest on day 24 and slightly lower on day 32. The majority of gonadotrophinsensitive follicles contain androgen in the follicular fluid and more developed follicles show aromatase activity, which causes oestrogen presence in the follicular fluid (Scaramuzzi et al. 1993; Strmšnik et al. 2002). We measured only approximately half sized follicles, unlike those described by Strmšnik et al. (2002). There is a clear line in the size of follicles when they become gonadotrophin-dependent and are selected for ovulation (Driancourt 2001). The majority of follicles $>4 \mathrm{~mm}$ in the follicular phase become preovulatory.

In puerperium the rate of atresia was highest on day 32; this proportion does not reach the rate described by various authors (Hsueh et al. 1994; Tilly et al. 1992; Rosales-Torres et al. 2000). In the follicles after cavum formation atretic marks begin from the follicle periphery - mostly from granulose and theca cells (Hasanzadeh and Sadrkhanloo 2000). The rate of atresia in the small antral follicle population is highest on day 32 post partum and is twofold higher than in cyclic ewes (Driancourt et al. 1990). When the developed antral follicles become gonadotrophin-dependent, they are more sensitive to atresia (Campbell et al. 1995).

Follicular atresia in the majority of mammals is primarily induced by programmed cell death or apoptosis of granulose and theca cells. The apoptosis is characterized by fragmentation of internucleosomal DNA, cell shrinkage, bubbling of plasma membrane and apoptotic body formation (Hsu and Hsueh 2000) which we took into consideration at the image analysis using PC System for image processing LUCIA-G ver. 4.71. Particularly degradation of DNA is detectable as the chain by polyacrylamide gel electrophoresis (PAGE) and also in the tissue sections by pycnotic bodies staining using TUNEL labelling (terminal deoxy-UTP nick end labelling) or similar methods used for bovine ovaries (Van Wezel et al. 1999; Yahia Khandoker et al. 2001; Clark et al. 2004; Yu et al. 2004).

In conclusion, more than half of the total number of antral follicles visible on the ovary 
surface are prepared for recruitment and this number is highest at the end of post partum involution of the reproductive tract in the Improved Valachian sheep breed. Follicle selection connected with a relatively low rate of atresia on day 32 enables the ovary to select more preovulatory follicles for the dominance process and thus also the occurrence of double ovulations.

\section{Histologické a USG aspekty folikulogenézy oviec v popôrodnom období po jarnom bahnení}

Čas prvej ovulácie po pôrode závisí od plemena, kŕmnych podmienok, ročnej doby, dížky dojčenia jahniat a následnej galaktopoézy. Ciel'om práce bolo analyzovat' stav folikulov po pôrode u nelaktujúcich oviec. Laparotómia s následnou ovariektómiou bola vykonaná po odstavení jahniat (na jar) na 17., 24. a 32. deň po pôrode. Vaječníky boli analyzované ultrasonograficky použitím 5,0 MHz lineárnej sondy a 7,5 MHz konvexnej sondy. Údaje o folikuloch získané analyzovaním ultrasonogramov boli vyhodnotené kvantitatívne a kvalitatívne. Vaječníky boli odobraté na konci laparotómie a fixované v 10\% formalíne. Rezy tkanív vaječníkov boli ofarbené hematoxilínom a eozínom a farbením podl'a Azana. Histologické preparáty boli študované mikroskopicky a analyzované programom LUCIA-G verzia 4.71. Rozdiely vo vel'kostiach vaječníkov neboli štatisticky signifikantné. Počet folikulov $<3 \mathrm{~mm}$ monitorovaných USG na 32. deň bol zvýšený na rozdiel od 17. dňa postpartálneho obdobia. Analýza obrazu rezov vaječníkov ukázala signifikantný nárast celkového počtu folikulov $(P<0.05)$ a folikulov $\geq 3 \mathrm{~mm}(P<0.001)$. Stupeň atrézie vykazoval $82 \%$ na 17 . deň a $89 \%$ na 32 . deň post partum. Zaznamenali sme jednu ovuláciu na 17. deň a dvojité ovulácie na 24. a 32. deň popôrodného obdobia. Viac ako polovica celkového počtu dutinových folikulov viditel'ných na povrchu vaječníkov je pripravených pre nábor a tento počet je najvyšší na 32. deň puerpéria. Výber folikulov spojený s relatívne nízkym pomerom atrézie a zodpovedajúcou vel'kost'ou preovulačného folikulu umožňuje vyselektovat' viac folikulov pre proces dominancie, a teda aj výskyt dvojitých ovulácií.

\section{Acknowledgement}

The work was supported by the grant VEGA 1/0612/03, ŠPVV-2003SP 270280 D 020280 D02 and AV 4/0113/06.

\section{References}

BARTLEWSKI PM, BEARD AP, COOK SJ, CHANDOLIA RK, HONARAMOOZ A, RAWLINGS NC 1999: Ovarian antral follicular dynamics and their relationships with endocrine variables throughout the oestrous cycle in breeds of sheep differing in prolificacy. J Reprod Fertil 115: 111-124

BARTLEWSKI PM, BEARD AP, RAWLINGS NC 2000: Ultrasonographic study of ovarian function during early pregnancy and after parturition in the ewe. Theriogenology 53: 673-689

BATTOCCHIO M, GABAI G, MOLLO A, VERONESI MC, SOLDANO F, BONO G, CAIROLI F 1999: Agreement between ultrasonographic classification of the CL and plasma progesterone concentration in dairy cows. Theriogenology 51: 1059-1069

CAMPBELL BK, SCARAMUZZI RJ, WEBB R 1995: Control of antral follicle development and selection in sheep and cattle. J Reprod Fertil Suppl 49: 335-350

CLARK LJ, IRVING-RODGERS HF, DHARMARAJAN AM, RODGERS RJ 2004: Theca Interna: The Other Side of Bovine Follicular Atresia. Biol Reprod 71: 1071-1078

DICKIE AM, PATERSON C, ANDERSON JLM, BOYD JS 1999: Determination of corpora lutea numbers in Booroola-Texel ewes using transrectal ultrasound. Theriogenology 51: 1209-1224

DRIANCOURT MA 2001: Regulation of ovarian follicular dynamics in farm animals. Implications for manipulation of reproduction. Theriogenology 55: 1211-1239

DRIANCOURT MA, CASTONGUAY F, BINDON BM, PIPER LR, QUIRKE JF, HANRAHAN JP 1990: Ovarian follicular dynamics in lines of sheep (Finn, Merinos) selected on ovulation rate. J Anim Sci 68: 2034-2041 
FRICKE PM 2002: Scanning the future - ultrasonography as a reproductive management tool for dairy cattle. J Dairy Sci 85: 1918-1926

GÁBOR GY, TÓTH F, SZÁSZ F, PETRÓ T, GYÖRKÖS I 2004: Ways of decreasing the period between calvings in dairy cows. 2. Oestrus induction and ovulation synchronisation methods (In Hungarian). Magy Allatorv Lapja 126: 658-663

GONG JG, ARMSTRONG DG, BAXTER G, HOGG CO, GARNSWORTHY PC, WEBB R 2002: The effect of increased dietary intake on superovulatory response to FSH in heifers. Theriogenology 57: 1591-1602

GRIFFIN PG, GINTHER OJ 1992: Research applications of ultrasonic imaging in reproductive biology. J Anim Sci 70: 935-972

GRYGAR I, KUDLÁČ E 1997: Sonografie u krávy. Sonografie u malých přežvýkavců (Cow sonography. Sonography in small ruminants.) (In Czech). In: Ultrasonografie ve veterinárním porodnictví a gynekologii, Nakladatelství Slezan, Hlučín, pp. 135-196

HALL JA, DAILEY RA, INSKEEP EK, LEWIS PE 1993: Influence of the corpus luteum of pregnancy on ovarian function in postpartum ewes. J Anim Sci 71: 3067-3072

HASANZADEH S, SADRKHANLOO R 2000: Study of ovarian follicular atresia in makoyee ewes in different stages of estrous cycle and different seasons of a year. J Fac Vet Med Univ Tehran 55: 81-86; 34 ref

HERNANDEZ X, BODIN L, CHESNEAU D, GUILLAUME D, ALLAIN D, CHEMINEAU P, MALPAUX B, MIGAUD M 2005: Relationship between MT1 melatonin receptor gene polymorphism and seasonal physiological responses in Ile-de-France ewes. Reprod Nutr Dev 45: 151-162

HSU SY, HSUEH AWJ 2000: Tissue-specific Bcl2-protein partners in apoptosis: An ovarian paradigm. Physiol Rev 80: 593-614

HSUEH AJ, BILLIG H, TSAFRIRI A 1994: Ovarian follicle atresia: a hormonally controlled apoptotic process. Endocr Rev 15: 707-724

HUNTER MG, ROBINSON RS, MANN GE, WEBB R 2004: Endocrine and paracrine control of follicular development and ovulation rate in farm species. Anim Reprod Sci 82-83: 461-477

HUSZENICZA G, KULCSAR M, NIKOLIC JA, SCHMIDT J, KORODI P, KATAI L, DIELEMAN S, RIBICZEI-SZABO P, RUDAS P 1999: Plasma leptin concetration and its interrelation with some blood metabolites, metabolic hormones and the resumption of cyclic ovarian function in postpartum dairy cows supplemented with monensin or inert fat in feed. In: DISKIN MG. (Ed.): Fertility in the high-producing dairy cow. Occ Publ Br Soc Anim Sci 26: 405-409

LAZAR G, POŠIVÁK J, VALOCKÝ I, KARAHUTOVÁ L, KAČMÁRIK J, ČURLÍK J, LAZAR P, MARAČEK I, CIGÁNKOVÁ V, MACÁK V, NOVOTNÝ F 2004: Laparoskopické monitorovanie ovariálnej aktivity muflónov (Laparoscopic monitoring of the ovarian activity in mouflon), (in Slovak). In: Zborník referátov "7. Košický morfologický deň”. Košice, 28. 5. 2004. UVL Košice, pp. 66-168

MARION GB, GIER HT, CHOUDARY JB 1968: Micromorphology of the bovine ovarian follicular system. J Anim Sci 27: 451-465

NĚMEČEK L 1996: Anesteziológia (Anaestesiology), (in Slovak). In: JANDA J, LEDECKÝ V. a kol.: V̌̌eobecná veterinárna chirurgia, Datahelp Košice, pp. 70-113

NOTTER DR, COCKETT NE, HADFIELD TS 2003: Evaluation of melatonin receptor 1a as a candidate gene influencing reproduction in a fall-lambing sheep flock. J Anim Sci 81: 912-917

ROSALES-TORRES AM, AVALOS-RODRÍGUEZ A, VERGARA-ONOFRE M, HERNÁNDEZ-PERÉZ O, BALLESTEROS LM, GARCÍA-MACEDO R, ORTÍZ-NAVARRETE V, ROSADO A 2000: Multiparametric study of atresia in ewe antral follicles: Histology, flow cytometry, internucleosomal DNA fragmentation, and lysosomal enzyme activities in granulosa cells and follicular fluid. Mol Reprod Dev 55: 270-281

SCARAMUZZI RJ, ADAMS NR, BAIRD DT, CAMPBELL BK, DAWNING JA, FINDLAY JK, HENDERSON KM, MARTIN GB, McNATTY KP, McNEILLY AS, TSONIS CG 1993: A model for follicle selection and the determination of ovulation rate in the ewe. Reprod Fertil Dev 5: 459-478

SCHRICK FN, SURFACE RA, PRITCHARD JY, DAILEY RA, TOWNSEND EC, INSKEEP EK 1993: Ovarian structures during the oestrous cycle and early pregnancy in ewes. Biol Reprod 49: 1133-1140

STENBAK TK, REDMER DA, BERGINSKI HR, ERICKSON AS, NAVANUKRAW C, TOUTGES MJ, BILSKI JJ, KIRSCH JD, KRAFT KC, REYNOLDS LP, GRAZUL-BILSKA AT 2001: Effects of follicle stimulating hormone (FSH) on follicular development, oocyte retrieval, and in vitro fertilization (IVF) in ewes during breeding season and seasonal anestrous. Theriogenology 56: 51-64

STRMŠNIK L, POGAČNIK M, ČEBULJ KADUNC N, KOSEC M 2002: Examination of oestrus cycle and early pregnancy in sheep using transrectal ultrasonography. Slov Vet Res 39: 47-58

TILLY JL, KOWALSKI KI, SCHOMBERG DW, HSUES AJ 1992: Apoptosis in atretic ovarian follicles is associated with selective decreases in messenger ribonucleic acid transcripts for gonadotropin receptors and cytochrome P450 aromatase. Endocrinology 131: 1670-1676

VACEK Z 1990: Histologická technika (Histologic technique), (in Slovak). In: Histológia a histologická technika. Vydavatel'stvo Osveta, pp. 267-488 (ISBN 80-217-0084-X).

VAN WEZEL IL, DHARMARAJAN AM, LAVRANOS TC, RODGERS RJ 1999: Evidence for Alternative Pathways of Granulosa Cell Death in Healthy and Slightly Atretic Bovine Antral Follicles. Endocrinology 140: 2602-2612 
YAHIA KHANDOKER MAM, IMAI K, TAKAHASHI T, HASHIZUME K 2001: Role of gelatinase on follicular atresia in the bovine ovary. Biol Reprod 65: 726-732

YU YS, SUI HS, HAN ZB, LI W, LUO MJ, TAN JH 2004: Apoptosis in granulosa cells during follicular atresia: relationship with steroids and insulin-like growth factors. Cell Res 14: 341-346 
Plate III

Vlčková R. et al.: Histological and ... pp. 65-72
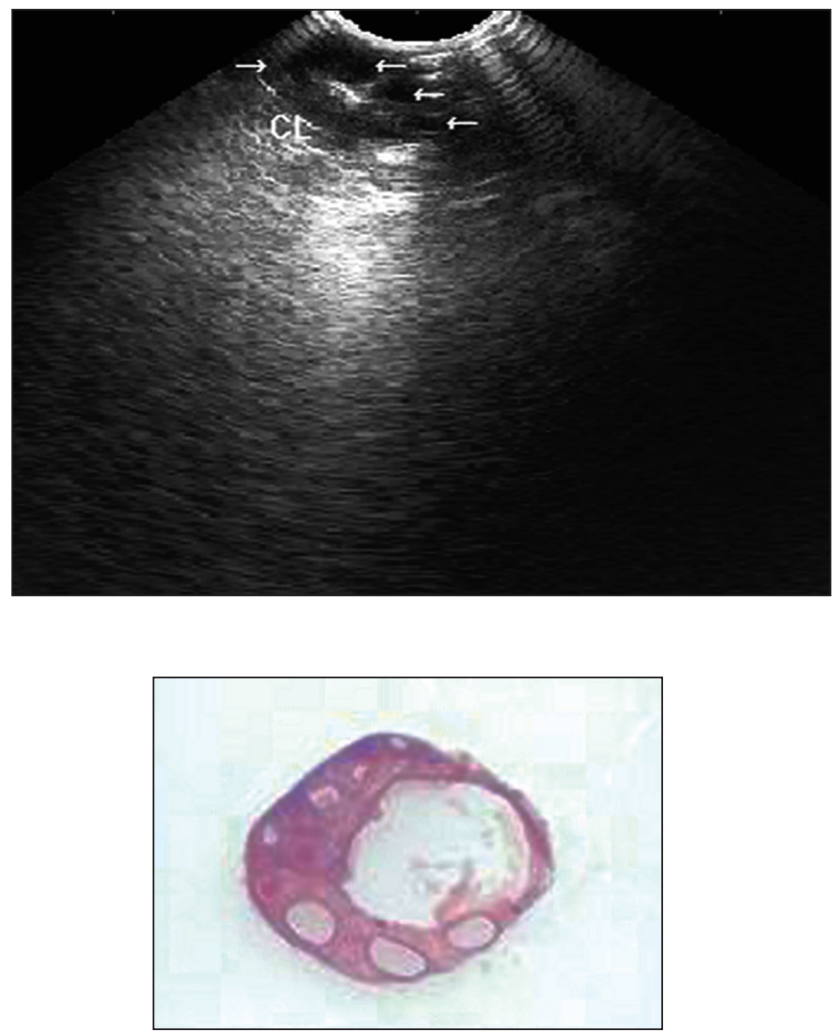

Fig. 2. Photographic reproduction of ultrasonogram of the ewe ovary on day 24 postpartum. Image obtained using an ESAOTE Falco echo camera equipped with a 7.5-MHz convex transducer was recorded on diskettes. Ovarian stroma is shown in light grey, antral follicles in black (anechoic follicular fluid, arrows) and CL in dark grey (echoic luteal tissue). For comparison, section through the ovary shows the largest follicle that undergoes atresia. 